\title{
Soil moisture as determinant of the seasonal soil co2 emission: evidence from central siberia
}

\section{Anastasia Vladimirovna Makhnykina ( $\nabla$ sunlife1408@yandex.ru )}

Siberian Federal University: Sibirskij federal'nyj universitet https://orcid.org/0000-0002-2324-3975

\section{Ivan Ivanovich Tychkov}

Siberian Federal University: Sibirskij federal'nyj universitet

\section{Anatoly Stanislavovich Prokushkin}

Sukachev Forestry Institute SB RAS: Institut lesa imeni V N Sukaceva SO RAN

Anton Igorevich Pyzhev

Siberian Federal University: Sibirskij federal'nyj universitet

\section{Eugene Alexandrovich Vaganov}

Siberian Federal University: Sibirskij federal'nyj universitet

\section{Research}

Keywords: soil respiration, carbon cycle, boreal forest, $\mathrm{CO} 2$ flux, modeling, exponential model, soil temperature, soil moisture

Posted Date: August 17th, 2021

DOl: https://doi.org/10.21203/rs.3.rs-783488/v1

License: (c) (i) This work is licensed under a Creative Commons Attribution 4.0 International License. Read Full License 
SOIL MOISTURE AS DETERMINANT OF THE SEASONAL SOIL $\mathrm{CO}_{2}$ EMISSION: EVIDENCE FROM CENTRAL SIBERIA

\author{
A.V. Makhnykina ${ }^{1,2^{*}}$, I.I. Tychkov ${ }^{1}$, A.S. Prokushkin ${ }^{1,2}$, A.I. Pyzhev ${ }^{1,3}$ and E.A. Vaganov ${ }^{1,2,3}$ \\ * Correspondence: amakhnykina@sfu-kras.ru \\ ${ }^{1}$ Siberian Federal University 660041, Krasnoyarsk, Russia \\ ${ }^{2}$ V.N. Sukachev Institute of Forest, Siberian Branch of the Russian Academy of Sciences \\ 660036, Krasnoyarsk, Russia \\ ${ }^{3}$ Center for Forest Ecology and Productivity, Russian Academy of Sciences 117997, Moscow, \\ Russia
}

\begin{abstract}
Background: The soils of the boreal zone contain significant reserves of carbon, therefore, their response to current climate changes will significantly affect the sustainability of forest ecosystems and the future concentration of $\mathrm{CO}_{2}$ in the atmosphere. When modeling soil emission, it is necessary to focus on the main soil environment factors. In this paper, a simple exponential model of the soil $\mathrm{CO}_{2}$ emissions growth was modified by introducing an additional parameter - the threshold soil moisture in different types of ecosystems based on the direct measurements.
\end{abstract}

Results: The developed model adequately reflects the dynamic changes in soil emission for different types of ecosystems. This result was achieved by including moisture as a second environmental factor besides temperature, describing changes in soil $\mathrm{CO}_{2}$ emissions during the summer period. The error of direct measurements for all measuring seasons was about $20 \%$ of the values of direct measurements of the $\mathrm{CO}_{2}$ flux. Note that such a high error was observed once per season in early and mid-June, reaching $60-80 \%$ on some days. Our models demonstrate in the season with the highest amount of precipitation the smallest differences in modeled fluxes 
about $15-20 \%$, which indirectly indicates that the emission flux is not inhibited by insufficient moisture in this season.

Conclusions: The final model application depends on the characteristics of the microclimatic conditions of a particular ecosystem, namely, a factor that has a limiting effect on the biological processes. When studying the functional role of boreal forest ecosystems the moisture conditions consideration is crucial to explain the atmospheric $\mathrm{CO}_{2}$ emission processes.

Keywords: soil respiration, carbon cycle, boreal forest, $\mathrm{CO}_{2}$ flux, modeling, exponential model, soil temperature, soil moisture

\section{Introduction}

The spatial and temporal variability of soil $\mathrm{CO}_{2}$ emissions in combination with their main determinants are not clear enough and that hampers the development of relevant models of carbon emissions (Zeng et al. 2005). The ecological systems are usually explained with nonlinear, multicomponent and hierarchical relationships (Lee et al. 2004). When modeling the dynamics of carbon in the ecosystem, one of the most important and commonly used dependency is the nonlinear temperature sensitivity of soil respiration (Rs).

Soil temperature is usually a factor that reliably describes the changes in $R_{s}$, however due to the complexity of the soil environment most researchers rely on empirical models instead of process models (Raich and Schlesinger 1992; Janssens and Pilegaard 2003). It is assumed that $\mathrm{Q}_{10}$ function is a good modeling tool to explain the variability in the total annual soil respiration, as it combines all processes that can affect the seasonal and annual soil respiration (Davidson et al. 1998, Janssens and Pilegaard 2003, Yuste et al. 2004). However, the use of the well-known Arrhenius and $\mathrm{Q}_{10}$ functions to describe the exponential response of Rs to temperature has been criticized (Xu and Qi 2001, Janssens and Pilegaard 2003; Yuste et al. 2004) because of their similar temperature sensitivity over a wide range of soil temperatures (Lloyd and Taylor 1994). There is empirical evidence that the temperature sensitivity of $\mathrm{R}_{\mathrm{s}}$ is declining amid rising the soil 
temperature when measured within one study area and also between different ecosystems (Janssens and Pilegaard 2003, Kirschbaum 1995, Lloyd and Taylor 1994, Reichstein et al. 2002). A decrease in the temperature sensitivity of soil respiration during drought was recorded (Borken et al. 1999, Yuste et al. 2003, Janssens and Pilegaard 2003, Lavigne et al. 2004, Reichstein et al. 2002, Xu and Qi 2001). Seasonal or more detailed temporal resolution analysis is imperative to improve understanding of the interactions between environmental variables and $R_{s}$.

A number of studies have established the dependence of the soil respiration rate on soil moisture and temperature (e.g. Lloyd and Taylor 1994, Davidson et al. 1998, Xu and Qi 2001). However, it is still unclear how $\mathrm{Q}_{10}$ is influenced by other climatic factors besides temperature (Lloyd and Taylor 1994, Shibistova et al. 2002, Yuste et al. 2003, Davidson and Janssens 2006). There are several evidences of empirical measurements that demonstrated relationships between soil respiration, temperature, and moisture conditions (Oberbauer et al. 1992, Hanson et al. 1993, Howard and Howard 1993, Raich and Potter 1995, Davidson et al. 1998). There are also models that take into account the parabolic effect of soil moisture (Mielnick and Dugas 2000), however, due to their development for the prairie, their application for other territories remains impossible.

The influence of temperature and moisture on $\mathrm{Q}_{10}$ is one of the determining factors to assess the climate change impact on ecosystem carbon fluxes (Kirschbaum 2000). Existing global ecosystem models, e.g. DGVMs (Levis et al. 2004), do not incur the different sensitivity of respiration of specific soils related to temperature and moisture.

An important issue in considering the dependence of soil emission on moisture conditions is the so-called "Birch effect" (Birch, 1964), which shows how periodic dryings and soil moisture regulate the process of soil organic matter mineralization and, as a result, act as one of the factors modifying soil $\mathrm{CO}_{2}$ emissions.

It was previously noted that for various ecosystems there are moisture conditions lead to increase in emissions is observed, however, as a rule, the range of optimum values of soil moisture is indicated (Suseela et al. 2012). In some studies, threshold moisture was employed 
(Luo and Zhou 2006) as a specific value of soil moisture for the ecosystem to remove water limitation of the emission process. At these systems the $\mathrm{R}_{\mathrm{s}}$ is controlled only by temperature changes. These values are precisely specific for a particular region and ecosystem and cannot be used for other ecosystems.

Our study is aimed at modifying the exponential model of soil $\mathrm{CO}_{2}$ emission by introducing an additional factor - soil moisture. The main goal is to test a nonlinear regression model of the seasonal dynamics of soil $\mathrm{CO}_{2}$ emission, taking into account the value of the threshold soil moisture for different ecosystems: lichen pine forest, green moss pine forest, mixed forest, destroyed area of lichen pine forest in the middle taiga region of Central Siberia. We focused on solving the following tasks: (a) assess the quality of the model for describing the seasonal dynamics of soil emission; (b) conduct a comparative analysis of the model's performance for different seasons and types of ecosystems; (c) check the accuracy of the model parameters using the averaged coefficients for all seasons.

\section{Materials and methods}

\section{Study area}

The research was carried out in the south of the Turukhansk region of the Krasnoyarsk Krai $\left(60^{\circ} 47^{\prime} \mathrm{N}, 89^{\circ} 21^{\prime} \mathrm{E}\right)$ within the Ket-Symskaya lowland near the scientific observatory "ZOTTO" (http://www.zottoproject.org).

The territory is located on the border of two climatic zones - subarctic and harsh continental. The average annual long-term temperature is $-3.7{ }^{\circ} \mathrm{C}$ according to instrumental observations from the Bor $\left(61^{\circ} 36^{\prime} \mathrm{N} 90^{\circ} 01^{\prime} \mathrm{E}\right)$ weather station (http://www.meteo.ru). The amplitude of the monthly temperature can reach $42{ }^{\circ} \mathrm{C}$. The average relative humidity is $76 \%$. The average total precipitation during the year is $590 \mathrm{~mm}$ (Pleshikov 2002).

\section{Measurements of soil $\mathrm{CO}_{2}$ emissions, soil temperature and soil moisture}


Direct measurements of soil emissions were carried out during the snowless period from June to September in 2012, 2013, 2015, 2016 and from August to September in 2017. The meteorological characteristics of the growing seasons are significantly different from each other, in particular, the amount of precipitation between seasons varied from 119 to $328 \mathrm{~mm}$ (Fig. 1), which is $54 \%$ lower and $23 \%$ higher than the average seasonal values respectively.

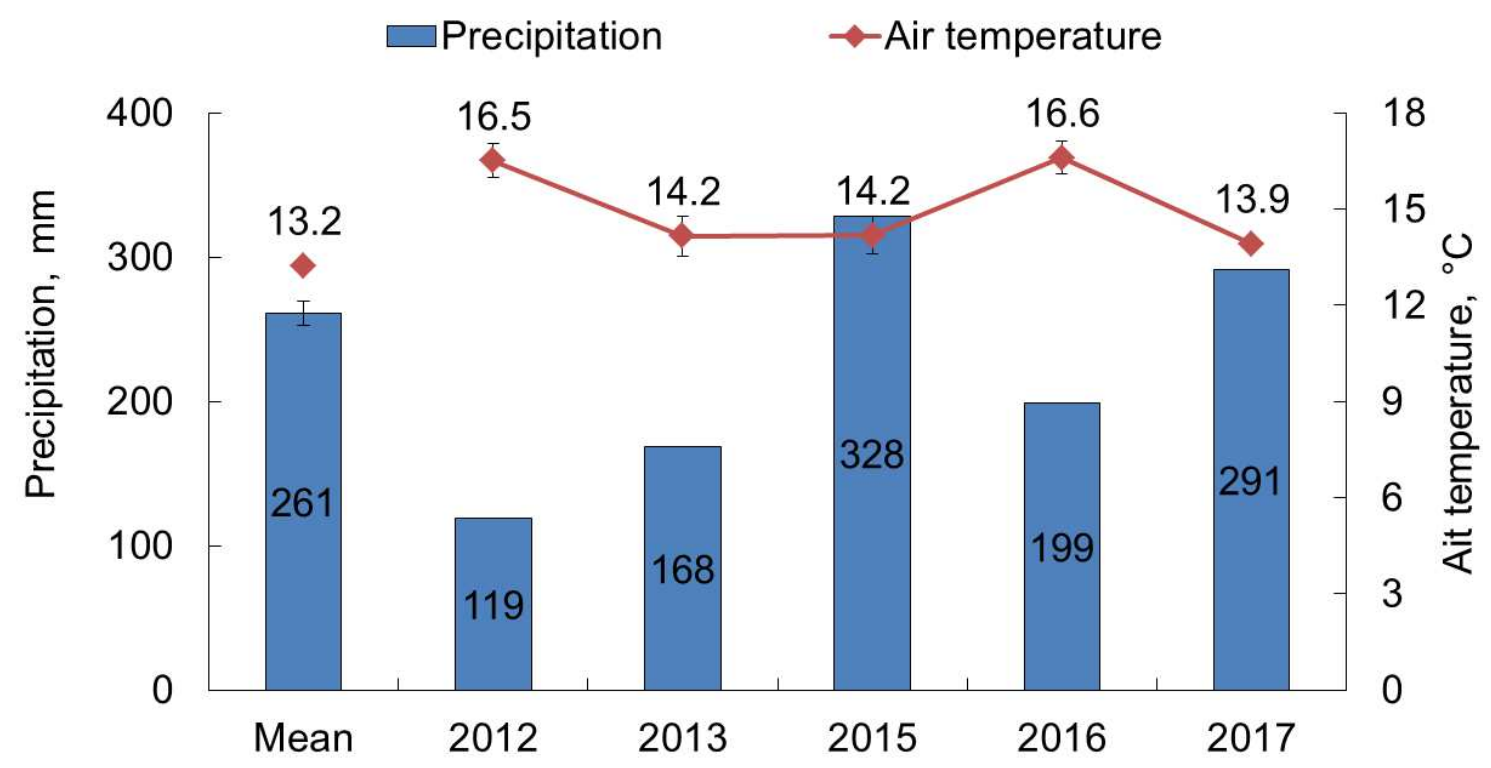

Fig. 1. Average temperature and total precipitation for the measurement period (June - September) for a 5-year period and average long-term values of these parameters at the Bor weather station (1936-2017 - air temperature dataset, 1966-2017 - precipitation dataset). Air temperature data is provided with standard errors.

The study sites were selected from the most abundant underline surfaces (Fig. 2): lichen pine forest, green moss pine forest, mixed forest, destroyed area (until 2005 it was represented by the lichen pine forest). The plots were located at a distance of 250 to $500 \mathrm{~m}$ from each other. The main characteristics of the studied ecosystems are presented in Table 1. 


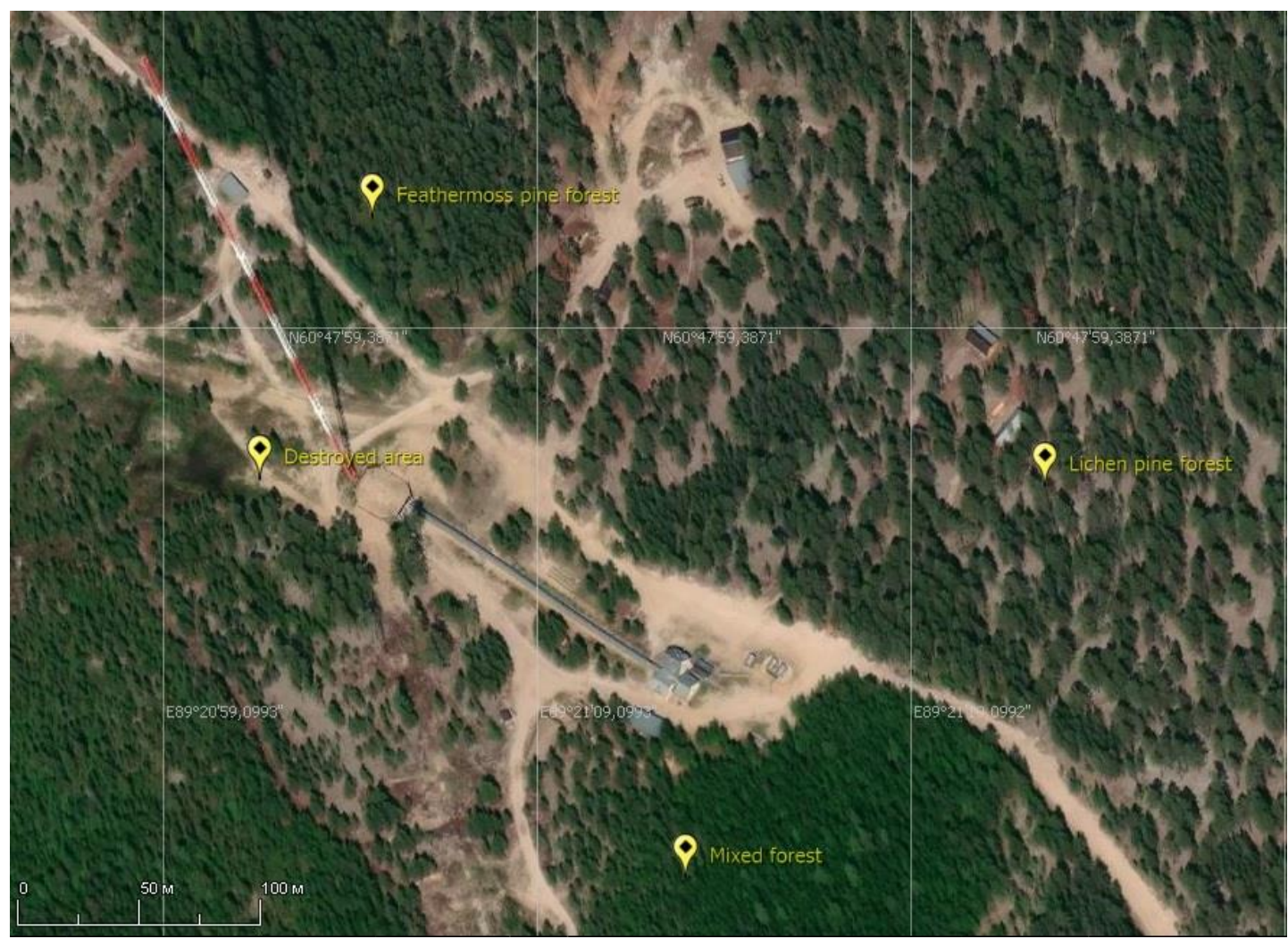

Fig. 2. Study sites mapping (source - SAS planet application, Mapbox map).

Table 1 Description of the studied ecosystems. Average values for soil temperature and moisture are given for a period of all the measuring seasons.

\begin{tabular}{|c|c|c|c|c|c|c|c|}
\hline Ecosystem & $\begin{array}{c}\text { Forest } \\
\text { age } \\
\text { (years) }\end{array}$ & $\begin{array}{c}\text { Forest } \\
\text { composition }\end{array}$ & $\begin{array}{c}\text { Mean soil } \\
\text { temperature } \\
\left({ }^{\circ} \mathrm{C}\right)\end{array}$ & $\begin{array}{c}\text { Mean soil } \\
\text { moisture } \\
\left(\mathbf{m}^{3} \mathbf{m}^{-3}\right)\end{array}$ & $\begin{array}{c}\text { Carbon } \\
\text { content (g } \\
\mathrm{C} \mathrm{kg}^{-1} \text { soil) }\end{array}$ & $\begin{array}{c}\text { Nitrogen } \\
\text { content (g } \\
\mathrm{N} \mathrm{kg}^{-1} \text { soil) }\end{array}$ & $\begin{array}{l}\mathrm{C} / \mathrm{N} \\
\text { ratio }\end{array}$ \\
\hline $\begin{array}{l}\text { Lichen pine } \\
\text { forest }\end{array}$ & 73 & $10 \mathrm{P}$ & $13.81 \pm 3.74$ & $0.21 \pm 0.09$ & $13.0 \pm 1.5$ & $0.6 \pm 0.1$ & 22 \\
\hline $\begin{array}{l}\text { Feathermoss } \\
\text { pine forest }\end{array}$ & 119 & $10 \mathrm{P}$ & $11.47 \pm 2.42$ & $0.26 \pm 0.12$ & $7.0 \pm 3.6$ & $0.3 \pm 0.1$ & 23 \\
\hline Mixed forest & 27 & $5 \mathrm{~B} 3 \mathrm{P} 2 \mathrm{~A}+\mathrm{S}$ & $12.98 \pm 2.55$ & $0.25 \pm 0.10$ & $14.9 \pm 1.4$ & $0.6 \pm 0.2$ & 25 \\
\hline Destroyed area & - & - & $20.04 \pm 7.23$ & $0.31 \pm 0.09$ & 7.3 & 0.4 & 18 \\
\hline
\end{tabular}

Measuring plastic (PVC - polyvinylchloride) rings were installed at the study sites before the start of measurements - in the spring of 2012. The soil emission efflux was measured using an automated system for measuring $\mathrm{CO}_{2}$ fluxes from the soil surface based on the infrared gas analyzer a LI-8100A (Li-cor Biogeosciences Inc., Lincoln, USA). The frequency of measurements for the season was at least 5 times a month for all ecosystem types. Direct measurements of soil temperature and moisture were provided directly for each measurement of 
soil $\mathrm{CO}_{2}$ emission fluxes. Temperature measurements were carried out at three depths $-5,10$, and $15 \mathrm{~cm}$ from the soil surface using a Soil Temperature Probe Type E (Omega, USA). A Theta Probe Model ML2x moisture meter produced by Delta T Devices Ltd., UK was used to measure the soil moisture content SWC - $5 \mathrm{~cm}$ from the soil surface (Makhnykina et al. 2016).

\section{Modeling seasonal soil emissions}

The calculation of soil $\mathrm{CO}_{2}$ emissions was carried out according to two models: 1 - the classical Lloyd-Taylor exponential model of the dependence of soil emission on the temperature ("T model") and 2 - a nonlinear regression model ("T-SWC model") with a newly introduced parameter - the threshold soil moisture for different ecosystems.

The $\mathrm{T}$ model is described by the following equation (Lloyd, Taylor, 1994): $E^{T}{ }_{C O 2}=E_{0} \times \exp \left(\alpha * T_{s}\right)$.

where $E_{0}, \alpha$ are parameters reflecting the sensitivity of the flow to a certain initial value of emission and changes in soil temperature, respectively.

The T-SWC model is based on the modification of the exponential model considering the parabolic effect of moisture and the introduction of an additional factor - the threshold soil moisture, specific for different types of ecosystems - $\beta_{0}$ :

$$
E^{T-S W C} \mathrm{CO}_{2}=\beta_{0} * E_{0} * \exp (\alpha * T) * \exp \left(\beta * S W C^{2}\right) .
$$

The threshold soil moisture was defined as the moisture content (Table 2) that corresponds to the minimum soil moisture at which a significant correlation is achieved between soil temperature and soil $\mathrm{CO}_{2}$ emission flux during the growing season. In this case, in contrast to our previous work (Makhnykina et al. 2020) where we used an exponential relationship between emission and temperature, all calculations were performed using a linear function. The remaining steps of the algorithm for calculating the threshold moisture content are identical.

Table 2 Values of threshold soil moisture $\left(\beta_{0}\right)$ for different types of ecosystems, $\mathrm{m}^{3} \mathrm{~m}^{-3}$. 


\begin{tabular}{lc}
\hline \multicolumn{1}{c}{ Ecosystem } & $\beta_{0}$ \\
\hline Lichen pine forest & 0.32 \\
Green moss pine forest & 0.22 \\
Mixed forest & 0.25 \\
Destroyed area & 0.26 \\
\hline
\end{tabular}

The study of seasonal dynamics was also accompanied by the use of a daily set of soil temperature and moisture data. Continuous measurements for each ecosystem were obtained by a linear transformation of data from a measuring station located close by the study area (http://www.zottoproject.org). The measurements were a dataset for a depth of $8 \mathrm{~cm}$ with a 10 minute resolution. The procedure for calculating daily values of soil temperature and moisture was carried out for each measurement season and type of ecosystem in the period from June 1 to September 30 included (Table 3).

Table 3 Equations for calculating daily measurements by temperature $(\mathrm{T})$ and soil moisture (SWC) for the lichen pine forest ( $\mathrm{p}$ - permanent measurements): $\mathrm{T}_{\mathrm{p}}-$ soil temperature, $\mathrm{SWC}_{\mathrm{p}}-$ soil moisture from the depth $8 \mathrm{~cm}$ from the measuring station.

\begin{tabular}{ccc}
\hline Year & Soil temperature $\left(\mathrm{T}_{\mathrm{s}}\right)$ & Soil moisture $(\mathrm{SWC})$ \\
\hline 2012 & $\mathrm{~T}_{\mathrm{s}}=1.61 * \mathrm{~T}_{\mathrm{p}}-5.38\left(\mathrm{R}^{2}=0.87\right)$ & $\mathrm{SWC}=4.10 * \mathrm{SWC}_{\mathrm{p}}+5.10\left(\mathrm{R}^{2}=0.83\right)$ \\
2013 & $\mathrm{~T}_{\mathrm{s}}=1.21 * \mathrm{~T}_{\mathrm{p}}-1.17\left(\mathrm{R}^{2}=0.94\right)$ & $\mathrm{SWC}=2.86 * \mathrm{SWC}_{\mathrm{p}}+4.32\left(\mathrm{R}^{2}=0.85\right)$ \\
2015 & $\mathrm{~T}_{\mathrm{s}}=1.20 * \mathrm{~T}_{\mathrm{p}}-0.73\left(\mathrm{R}^{2}=0.86\right)$ & $\mathrm{SWC}=2.74 * \mathrm{SWC}_{\mathrm{p}}+6.51\left(\mathrm{R}^{2}=0.75\right)$ \\
2016 & $\mathrm{~T}_{\mathrm{s}}=1.22 * \mathrm{~T}_{\mathrm{p}}-1.88\left(\mathrm{R}^{2}=0.76\right)$ & $\mathrm{SWC}=3.43 * \mathrm{SWC}_{\mathrm{p}}+6.75\left(\mathrm{R}^{2}=0.74\right)$ \\
2017 & $\mathrm{~T}_{\mathrm{s}}=1.19 * \mathrm{~T}_{\mathrm{p}}-1.63\left(\mathrm{R}^{2}=0.98\right)$ & $\mathrm{SWC}=2.20 * \mathrm{SWC}_{\mathrm{p}}+14.62\left(\mathrm{R}^{2}=0.53\right)$ \\
\hline
\end{tabular}

\section{Parameterization and estimation of model coefficients}

Data processing and further calculations of the model coefficients were obtained by means of the R software environment (R Core Team 2020) with the stargazer (Hlavac and Mare 2018), tidyverse (Wickham et al. 2019), olsrr (Hebbali 2020) packages.

The models were linearized to the following form: 
$1-\mathrm{T}$ model: $\ln \left(E^{T} \mathrm{CO}_{2}\right)=\ln \left(E_{0}\right)+\alpha T$;

2 - T-SWC model: $\ln \left(E^{T-S W C} \mathrm{CO}_{2}\right)=\ln \left(E_{0}\right)+\alpha T+\ln (\beta)$.

We used adjusted coefficient of determination $\mathrm{R}^{2}$ (Koerts and Abrahamse 1970, Rencher and Pun 1980, Cameron and Windmeijer 1996) and the Akaike criterion (Akaike 1973) to estimate the goodness-of-fit and to select the best appropriate regression models.

\section{Results}

\section{Model coefficients estimation}

Based on the values of the coefficients $-\alpha, \beta$ (Tables 4-8), we made an assumption about the strength of the impact of the environmental factor on the $\mathrm{CO}_{2}$ emission rates in different ecosystem types. In this case, we considered $\alpha$ as an indicator of resistance to temperature changes and, accordingly, $\beta$ to moisture. After analyzing the obtained values of the coefficients, it can be noted that the temperature has a greater effect on the formation of the emission flux in the green moss pine forest ( $\alpha=0.111)$, and the moisture - in the lichen pine forest $(\beta=0.365)$. The values of the $\alpha$-coefficients are on average $24-56 \%$ lower than the $\beta$ values according to the T-SWC model for different ecosystems. An interesting fact is that in the destroyed area, an inverse dependence on soil moisture is obvious, since the value of the $\beta$ coefficient averaged over four measurement seasons is a negative.

Table 4 Models coefficients for all sites averaged over four seasons of measurements.

\begin{tabular}{|c|c|c|c|c|c|c|c|}
\hline Model & All years & $\alpha(\mathrm{SE})$ & $\beta$ (SE) & $\overline{\mathbf{E}_{0}}$ & $\mathbf{N}$ & Adj. $R^{2}$ & AIC \\
\hline \multirow[t]{4}{*}{$\mathrm{T}$ model } & Lichen pine forest & $\begin{array}{l}0.076 * * * \\
(0.008)\end{array}$ & - & 0.944 & 148 & 0.371 & 153.114 \\
\hline & Green moss pine forest & $\begin{array}{l}0.096 * * * \\
(0.012)\end{array}$ & - & 1.095 & 136 & 0.325 & 59.203 \\
\hline & Mixed forest & $\begin{array}{l}0.062 * * * \\
(0.010)\end{array}$ & - & 2.018 & 138 & 0.230 & 162.225 \\
\hline & Destroyed area & $\begin{array}{l}0.070 * * * \\
(0.013)\end{array}$ & - & 0.152 & 89 & 0.248 & 211.743 \\
\hline \multirow[t]{2}{*}{$\begin{array}{l}\text { T-SWC } \\
\text { model }\end{array}$} & Lichen pine forest & $\begin{array}{l}0.108 * * * \\
(0.008)\end{array}$ & $\begin{array}{l}0.365 * * * \\
(0.045)\end{array}$ & 0.231 & 148 & 0.566 & 99.391 \\
\hline & Green moss pine forest & $\begin{array}{l}0.111 * * * \\
(0.010)\end{array}$ & $\begin{array}{l}0.200 * * * \\
(0.027)\end{array}$ & 1.143 & 136 & 0.519 & 13.916 \\
\hline
\end{tabular}




\begin{tabular}{lllllll} 
Mixed forest & $\begin{array}{lll}0.064 * * * \\
(0.009)\end{array}$ & $\begin{array}{l}0.267 * * * \\
(0.045)\end{array}$ & 1.435 & 138 & 0.382 & 132.866 \\
Devastated area & $\begin{array}{l}0.079 * * * \\
(0.013)\end{array}$ & $\begin{array}{l}-0.157 * \\
(0.085)\end{array}$ & 1.407 & 89 & 0.267 & 210.315 \\
\hline
\end{tabular}

$p<0.1 ; \boldsymbol{p}<0.05 ; \mathrm{p}<0.01$

SE -standard error

$\mathrm{N}$ - number of observations

Adj. $\mathrm{R}^{2}$ - adjusted $\mathrm{R}^{2}$

AIC - Akaike Information Criterion

Based on the value of the $\beta$ coefficient, it is possible to form a series of ecosystems' sensitivity to moisture conditions, namely: lichen pine forest> mixed forest> green moss pine forest $>$ destroyed area. Our idea of introducing a specific value of the threshold moisture content makes it possible to analyze the biological characteristics of the functioning of different ecosystems, based on mathematical solutions.

In most cases $(80 \%)$ Adj. $\mathrm{R}^{2}$ according to the T-SWC model is always higher than according to the $\mathrm{T}$ model, namely with the exception of the 2017 season for the forested areas. In the 2017 season with a small number of measurements, both models showed similar results of this coefficient. However, in other seasons between coefficients of determination according to $\mathrm{T}$ and T-SWC models there was a significant difference: Adj. $\mathrm{R}^{2}$ according to the T-SWC model is on average higher, depending on the type of ecosystem and season, varying from 0.267 to 0.566 , while according to the $\mathrm{T}$ model it varied from 0.230 to 0.371 (Table 4). During the dry seasons of 2012 and 2013 the largest discrepancy was recorded for the green moss pine forest, according to the T model was 0.099 and 0.108 , respectively, which is significantly lower than according to T-SWC models for two seasons -0.315 and 0.470 .

In the season with the highest amount of precipitation (2015) the T and T-SWC models demonstrate the smallest deviation in the calculated flows, the maximum being about $15-20 \%$, which indirectly indicates that the emission flux is not inhibited by insufficient moisture in this season for the forested areas. The destroyed area is highlighted separately - in all the seasons considered, the simulation results for the two models show similar Adj. $\mathrm{R}^{2}$, which indicates a similar implementation of the models for this area. 
For a more detailed study of the quality of the models, the Akaike information criterion (AIC) was calculated. The main indicator when comparing models is the value of the criterion, namely, for a model with the most accurate set of parameters and a selected functional dependence, the value of the criterion will be less than for a model that describes the process under consideration less accurately. In forested areas, the T-SWC model shows better results than the $\mathrm{T}$ model. The exception is again the 2017 season. The variation in AIC values is significant, both within the same area and between the measurement seasons. Thus, the greatest scatter of the criterion values is observed on the destroyed area according to the coefficients averaged for all seasons, and among the forested sites, a mixed forest stands out. Moreover, according to the T model, the variation of the AIC values is always wider than according to the T-SWC model. The main differences in AIC values within the same area are associated with the use of averaged coefficients in the calculations - $\alpha, \beta$ for calculating the emission flux. It can be explained by a high deviation of the fluxes calculated from the average coefficients of $\mathrm{CO}_{2}$ fluxes from the real values of emissions. A feature of the destroyed site (Table 8) is that the AIC is insignificantly less according to the T model: e.g., 0.760 (T) and vs. 0.730 (T-SWC) in 2012. In the seasons 2013 and 2015 the AIC values are not significantly different, which may indicate the possible use of two models for calculating emission fluxes from this area.

\section{Modeling $\mathrm{CO}_{2}$ flows using the T-SWC model}

The T-SWC model demonstrates seasonal fluctuations in the soil $\mathrm{CO}_{2}$ emissions for seasons with different precipitation conditions (Fig. 1, 3). The maximum differences between the simulated fluxes using the T-SWC model with direct measurements for all considered seasons was about $20 \%$ for different ecosystems. Interestingly, in seasons with different moisture conditions, the greatest difference between the measured and modeled soil emission fluxes was observed at the same time intervals of the season, especially in the beginning - mid-June, reaching $60-80 \%$ in some days. The $\mathrm{T}$ model often show the higher variation with the direct measurements in 
dynamic changes of the soil emission during the season, but the average values of emissions for the season are close to the measured ones. Note that in the 2015 season, when heavy rainfalls were recorded, both the T-SWC and the T model show similar results, showing variations in soil $\mathrm{CO}_{2}$ fluxes over the season. This fact may indicate that in the absence of a precipitation deficit, one factor is sufficient - the soil temperature, to calculate the soil emission fluxes.
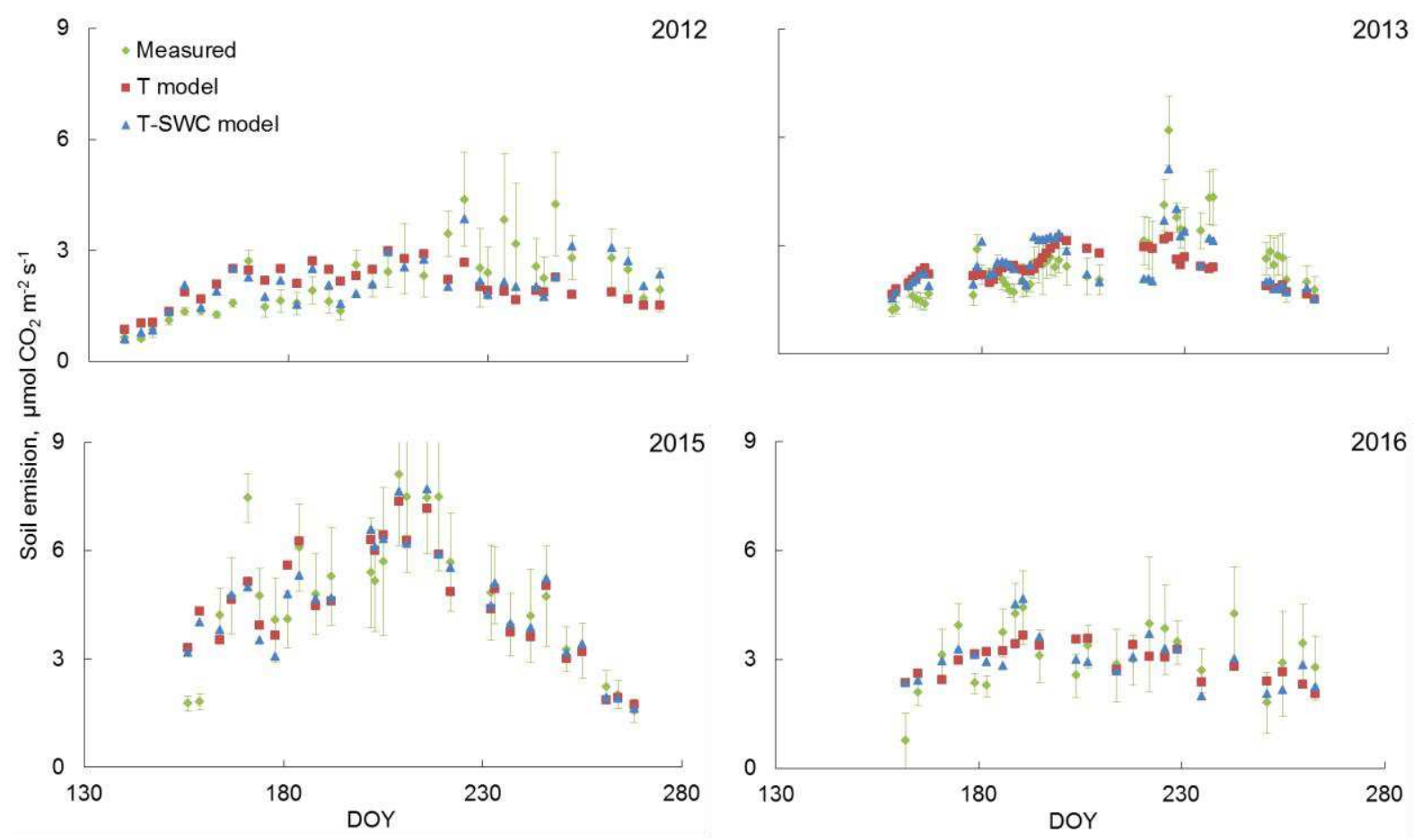

Fig. 3. Dynamics of soil emission for seasons with different moisture conditions for lichen pine forest. Red squares represent the simulation results for the T model, green rhombuses - direct measurements, blue triangles - the work of the T-SWC model.

For all forested areas (lichen pine forest, green moss pine forest, mixed forest) there is a general law: the biggest differences in $\mathrm{CO}_{2}$ fluxes measured and modeled by the T-SWC model are observed mainly at the beginning of the summer season: in the middle - at the end of June and in the second half of August reaching $60 \%$ in some days of measurements (Fig. 4). The T model does not record the peak values of emissions, and during periods of maximum growth of fluxes, the difference between the measured and obtained from the $\mathrm{T}$ model $\mathrm{CO}_{2}$ fluxes is about $25 \pm 4 \%$. With regard to the destroyed site, there is another feature. Throughout the 2013 season, 
the discrepancies between the $\mathrm{CO}_{2}$ fluxes measured and calculated using the $\mathrm{T}$ and $\mathrm{T}-\mathrm{SWC}$ models were insignificant and amounted to less than $10 \%$, which is presumably related to the origin of the site: the absence of structured soil horizons and ground cover could reduce the sensitivity of this ecosystem to moisture conditions. When comparing the destroyed area with the other considered, it was evident that the values of both measured and modeled flows are 6-10 times lower than in forested areas.

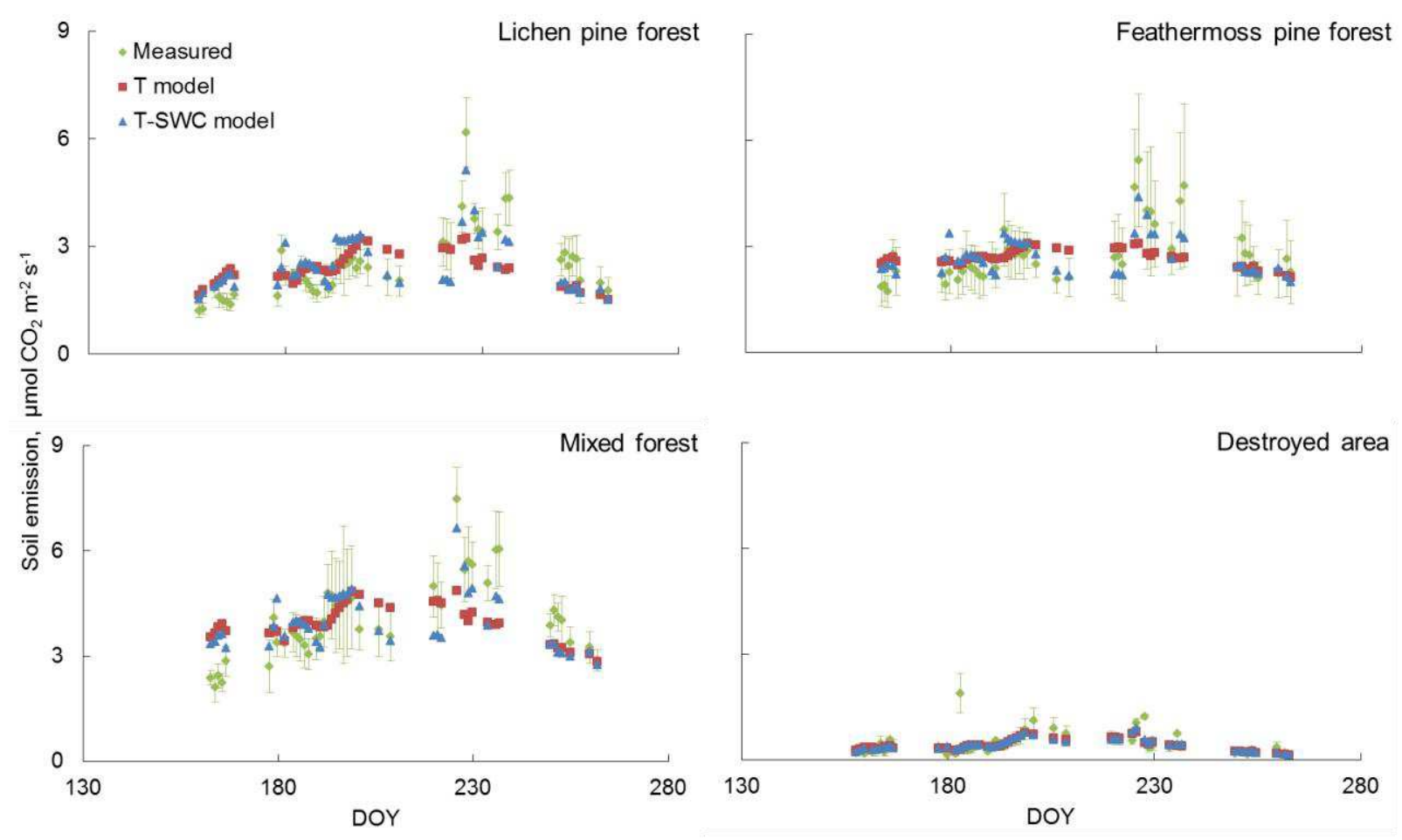

Fig. 4. Seasonal dynamics of soil emission in different seasons of measurements for different ecosystems in the 2013 season. Red squares represent the simulation results for the T model, green rhombuses - direct measurements, blue triangles - the work of the T-SWC model.

\section{Discussion}

In our work, based on experimental data, the threshold soil moisture for the middle taiga ecosystems of the Central Siberia region was introduced for the first time in the exponential model of soil emission as an additional parameter. The results obtained in the course of the study confirm that during the summer period, moisture conditions play an important and often decisive role in considering the dynamics of soil $\mathrm{CO}_{2}$ emission fluxes, which was previously emphasized 
in a number of studies (Tanaka 2001, Reichstein et al. 2003, Cook and Orchard 2008, GaumontGuay et al. 2014, Acosta et al. 2018, Monson et al. 2006, Liu et al. 2016). We compared two models at once, one of which is currently widely used for calculating soil emission on seasonal, annual, and interannual scales - the Lloyd-Taylor exponential model (1994).

The threshold soil moisture for each of the considered ecosystems are specific values that can be calculated by the algorithm represented in the study of Makhnykina et al. 2020. This parameter allows not only to observe the changes in seasonal dynamics of soil $\mathrm{CO}_{2}$ emissions more accurately, but also to establish how strong a specific ecosystem is limited in terms of moisture conditions. The lowest threshold moisture value was recorded in the green moss pine forest, which indicates its high resistance to changes in the precipitation conditions. The most sensitive was the lichen pine forest, which demonstrates a quick response to harsh changes in the amount of available moisture through changes in the emission rates.

\section{T-SWC model: estimates for different ecosystems and different seasons}

Based on the fact that the model of exponential growth of soil emission (Lloyd and Taylor 1994) predicts a permanent increase in $\mathrm{CO}_{2}$ emission rates with increasing temperature (Zeng et al. 2016, Yan et al. 2019), we assumed that the maximum fluxes will occur in the middle of growing season. However, if we consider this process by the example of seasons with different precipitation conditions and for ecosystems of different origins, some shortcomings of this model will be more obvious (Fig. 3, 4).

The exponential model modification is largely aimed to obtain the adequate estimates of the dynamic changes in the soil emission rates during the season. With the beginning of the growing season, a number of biological and physiological processes are activated (Shibistova et al. 2002, Kirschbaum 2000, Laganière et al. 2012), including the soil processes, which make a significant contribution to the formation of soil $\mathrm{CO}_{2}$ emissions. The introduction of the threshold moisture content $\left(\beta_{0}\right)$ into the exponential model of soil emission makes it possible not only to 
emphasize the importance of this factor for biological processes in the soil, but also account for the peculiarities of a particular ecosystem.

The T-SWC model fixed both periods of active growth and periods of decline in soil emission rates during the season. Registration of such events is under the increased interest, since they are one of the mechanisms of natural ecosystem regulation such as atmospheric $\mathrm{CO}_{2}$ sink (Piao et al. 2008). The seasons considered by us differed significantly in terms of precipitation conditions (Fig. 1), but the developed model adequately reflected the changes in soil emission for both season options with a deficit of precipitation $(2012,2013)$ and the waterlogged season (2015). These patterns were observed for all forested areas and characterized by the number of features.

In the green moss pine forest, the soil temperature during the season does not demonstrate significant changes, while the soil moisture is maintained at a relatively constant level throughout the season due to the powerful ground cover (the thickness of the moss-lichen layer reaches $20-25 \mathrm{~cm}$ ) and litter. We argue that the reason for the lowest threshold soil moisture in the considered ecosystem $\left(\beta_{0}=0.22\right)$. Obtained results are consistent with the previous work featuring the similar ecosystem in the boreal forests of Canada (Laganière et al. 2012) where it was shown that in a coniferous forest with a mossy ground cover, the average soil temperature was lower than in a mixed forest, which reflected in the magnitude of seasonal $\mathrm{CO}_{2}$ fluxes. Capturing the peculiarities of this ecosystem through the value of the threshold soil moisture in the T-SWC model, it was possible to obtain a high convergence of the modeled emission flux of $\mathrm{CO}_{2}$ with the data of direct measurements: during periods of maximum emission growth the discrepancy in the $\mathrm{CO}_{2}$ emission rates did not exceed $15 \%$.

Estimates of the T-SWC model for mixed forest also shows a high convergence of direct observation and modeled data in all studied seasons. The largest discrepancies in the peak emission rates are observed in 2013, accompanied by dry conditions throughout the season, about $15 \%$ (Fig. 1). Interestingly, the soil emission flux in a mixed forest, as an area with the 
highest biodiversity, is fairly accurately described by means of meteorological parameters solely such as soil temperature and moisture. However, some studies noted that the characteristics of the vegetation cover (Law et al. 2001, Acosta et al. 2013), the biomass of roots (Moyano et al. 2008) and microorganisms (Fekete et al. 2014), as well as the number of organic matter in the soil (Rayment and Jarvis 2000) are significant factors in the formation of the soil emission flux.

As noted earlier, the biggest sensitivity to changes in moisture conditions was recorded in a lichen pine forest. When considering the results of modeling using the T-SWC model for this site, it can be noted that the model clearly demonstrates the dynamics of soil $\mathrm{CO}_{2}$ emission fluxes. The largest discrepancies between the modeled fluxes and the initial ones were observed in the 2012 season, which is generally characterized as a season with a moisture deficit (Fig. 1). This feature of a particular season was reflected in the inhibition of respiratory activity until the middle of the season (Fig. 4). We suppose that the reason for such activity could be the suppression of biological processes, such as the decomposition of soil organic matter, the activity of soil heterotrophs (Hanson et al. 2000), as well as changes in individual soil properties aggregate structure, soil water capacity, surface tension, and others (Goebel et al. 2011) as a response to water shortage.

The destroyed area, due to its anthropogenic origin, demonstrates low sensitivity to both the influence of moisture and soil temperature (Fig. 4). The development of this site itself bears a number of significant differences in the rate of post-human intervention recovery, including emission rates (Karelin et al. 2020). Seasonal measurements at the site began 5 years after the disturbance, and now we can be sure that this time is not enough for the restoration of the territory as it is largely reflected in the emission fluxes.

\section{T and T-SWC models comparison}


The hydrothermal conditions of the site and the climatic characteristics of the measuring season have a significant effect on the formation of the soil emission flux, and they should be taken into account when modeling soil emission. It was noted in a number of studies that the annual $\mathrm{CO}_{2}$ flux from the soils is mainly controlled by temperature and can be predicted using only this environmental factor. Recently, however, there has been a greater focus on small-scale changes, both temporal and spatial (Scott-Denton et al. 2006, Hashimoto et al. 2015, Zeng et al. 2016, Acosta et al. 2018, Gebremichael et al. 2019).

Considering the role of moisture conditions during the growing season for forest ecosystems is especially relevant as they are sensitive to this effect. Mielnick et al. (2001) noted that the impulse response of soil emission to changes in moisture conditions can reflect in much more detail the dynamic changes in the rate of $\mathrm{CO}_{2}$ fluxes. For prairie region, they received estimates that reliably describe the seasonal and annual dynamics of soil emission; however, the model also had a drawback - focus on certain growing conditions, for which the model was originally created (Mielnick et al. 2001).

With regard to exponential models including only the temperature sensitivity of the soil emission flux, there are also a number of disadvantages when working on a seasonal scale. One of the most significant of them is a lack of seasonal fluctuations reflection in soil emission. Most probably explained by the missing element of the model, which describes the precipitation conditions. The inconsistency of the temperature model has already been noted (Xu and Qi 2001, Janssens and Pilegaard 2003, Yuste et al. 2004), however, according to the researchers, this could be resulted from insufficient consideration of other external factors, such as the diffusion of gases in the soil, hydrodynamic soil dispersion (Fang and Monkriff 1999), the presence of root or mycorrhizal exudates (Subke et al. 2006, Kuzyakov 2006), and others. This is a sort of proof of the complexity of the process of soil emission and its consideration of the ongoing dynamic fluctuations of a number of climatic environmental factors. However, it should be noted that the disadvantage of the multicomponent nature of the models is an additional set of specific 
parameters that are unique for a particular region and verification of these models for another territory does not provide adequate estimates.

If we consider the seasonal dynamics, which is represented by the T model (Fig. 4), then it is quite difficult to follow it in all forested areas. In the destroyed area without a ground cover, T, the model reflects real $\mathrm{CO}_{2}$ fluxes, since in this case the temperature is a sufficient factor for obtaining adequate estimates of the seasonal dynamics of soil emission. The development of destroyed areas is one of the most widely discussed at the present time (Yue-Lin et al. 2008, Han et al. 2018, Karelin et al. 2020) due to the rapid decline of natural forests because of anthropogenic actions. However, the intensity of disturbance and the recovery period are often determined by the origin of the ecosystem and climatic factors of the environment (Zhang et al. 2013, Xu et al. 2020). The response of disturbed ecosystems to climatic changes is also specific and is often determined by specific regional features.

\section{Conclusion}

According to the obtained results, the model developed by us demonstrates an adequate description of the seasonal dynamics for seasons with different precipitation conditions and for different ecosystems. The model parameters reflect the importance of the influence of each of the considered factors for a specific ecosystem. The model representing only the effect of temperature can be applicable for calculating the average flow for the season, but not for studying the seasonal dynamics of soil $\mathrm{CO}_{2}$ emissions.

The model application depends on the microclimatic conditions characteristics of a particular ecosystem, namely, a factor that has a limiting effect on the biological processes. Further development of the study can expand the number of sites and, accordingly, types of ecosystems where the unique values of the threshold moisture content could be found for further modeling the seasonal soil $\mathrm{CO}_{2}$ emissions. Thus, it confirms the idea of moisture conditions 
consideration as crucial when studying the functional role of boreal forest ecosystems - whether they act as a sink or a source of atmospheric $\mathrm{CO}_{2}$.

\section{Acknowledgments}

The authors of this study would like to thank all staff members of the International research station "ZOTTO" involved in the measurement process.

\section{Funding}

This study was supported by the Russian Science Foundation (grant no. 19-77-30015).

Calculations were made using partial financing from state assignment to the Centre for Forest Ecology and Productivity, Russian Academy of Sciences (project no. AAAA-A18118052400130-7). Data collection and discussion were made using partial financing from RFBR, Krasnoyarsk Territory and Krasnoyarsk Regional Fund of Science (project number 20-44243003).

\section{References}

Acosta M, Darenova E, Krupková L, Pavelka M (2018) Seasonal and inter-annual variability of soil $\mathrm{CO}_{2}$ efflux in a Norway spruce forest over an eight-year study. Agricultural and Forest Meteorology 256-257: 93-103. https://doi.org/10.1016/j.agrformet.2018.03.005

Akaike H (1973) Information theory and an extension of the maximum likelihood principle Springer, New York, NY: 199-213. https://doi.org/10.1007/978-1-4612-1694-0_15

Birch H F (1964) Mineralisation of plant nitrogen following alternate wet and dry conditions. Plant Soil 20: 43-49.

Borken W, Xu YJ, Brumme R, Lamersdorf N (1999) A climate change scenario for carbon dioxide and dissolved organic carbon fluxes from a temperate forest soil drought and 
rewetting effects. Soil Science Society of America Journal 63(6): 1848-1855. https://doi.org/10.2136/sssaj1999.6361848x

Cameron AC, Windmeijer FAG (1996) $\mathrm{R}^{2}$ measures for count data regression models with applications to health-care utilization. J. Business Econ. Stat. 14: 209-220. https://doi.org/10.2307/1392433

Cook FJ, Orchard VA (2008) Relationships between soil respiration and soil moisture. Soil Biology \& Biochemistry 40: 1013-1018. https://doi.org/10.1016/j.soilbio.2007.12.012

Gaumont-Guay D, Black TA, Barr AG, Griffis TJ, Jassal RS, Krishnan P, Grant N, Nesic Z (2014) Eight years of forest-floor $\mathrm{CO}_{2}$ exchange in a boreal black spruce forest: spatial integration and long-term temporal trends. Agric. For. Meteorol. 184: 25-35. https://doi.org/10.1016/j.agrformet.2013.08.010

Goebel M-O, Bachmann J, Reichstein M, Janssens IA, Guggenberger G (2011) Soil water repellency and its implications for organic matter decomposition - is there a link to extreme climatic events? Global Change Biology 17: 2640-2656. https://doi.org/10.1111/j.1365-2486.2011.02414.x

Han M, Shi B, Jin G (2018) Conversion of primary mixed forest into secondary broadleaved forest and coniferous plantations: Effects on temporal dynamics of soil $\mathrm{CO}_{2}$ efflux. Catena 162: 157-165. https://doi.org/10.1016/j.catena.2017.12.004

Hashimoto S, Carvalhais N, Ito A, Migliavacca M, Nishina K, Reichsten M (2015) Global spatiotemporal distribution of soil respiration modeled using a global database. Biogeosciences 12: 4121-4132. https://doi.org/10.5194/bg-12-4121-2015

Hebbali A (2020) olsrr: Tools for Building OLS Regression Models. R package version 0.5.3. https://CRAN.R-project.org/package=olsrr

Hlavac M (2018) stargazer: Well-Formatted Regression and Summary Statistics Tables. R package version 5.2.1. https://CRAN.R-project.org/package=stargazer 
Karelin D, Goryachkin S, Zazovskaya E, Shishkov V, Pochikalov A, Dolgikh A, Sirin A, Suvorov G, Badmaev N, Badmaeva N, Tsybenov Y, Kulikov A, Danilov P, Savinov G, Desyatkin A, Desyatkin R, Kraev G (2020) Greenhouse gas emission from the cold soils of Eurasia in natural setting and under human impact: Controls on spatial variability. Geoderma Regional 22: e00290.

Koerts J, Abrahamse APJ (1970) The correlation coefficient in the general linear model. Eur. Econ. Rev. 1: 401-427.

Kuzyakov Y (2006) Sources of $\mathrm{CO}_{2}$ efflux from soil and review of partitioning methods. Soil Biol. Biochem. 38(3): 425-448. https://doi.org/10.1016/j.soilbio.2005.08.020

Laganière J, Paré D, Bergeron Y, Chen HYH (2012) The effect of boreal forest composition on soil respiration is mediated through variations in soil temperature and $\mathrm{C}$ quality. Soil Biology \& Biochemistry 53: 18-27. https://doi.org/10.1016/j.soilbio.2012.04.024

Lee T-W, Zaumseil , Bao Z, Hsu J, Rogers JA (2004) Organic light-emitting diodes formed by soft contact lamination. PNAS 101(9): 429-433. https://doi.org/10.1073/pnas.0400055101

Levis S, Bonan GB, Vertenstein M, Oleson KW (2004) The community land model's dynamic global vegetation model (CLM-DGVM): technical description and user's guide. Terrestrial sciences. Section climate and global dynamics division. National center for atmospheric research boulder, Colorado: 66 .

Mielnick PC, Dugas WA (2000) Soil $\mathrm{CO}_{2}$ flux in a tall grass prairie. Soil Biology \& Biochemistry 32: 221-228. https://doi.org/10.1016/S0038-0717(99)00150-9

Mielnick PC, Dugas WA, Johnson HB, Polley HW, Sanabria J (2001) Net grassland carbon flux over a subambient to superambient $\mathrm{CO}_{2}$ gradient. Global Change Biology 7: 747-754. https://doi.org/10.1046/j.1354-1013.2001.00445.x

Oberbauer SF, Gillespie CT, Cheng W, Gebauer R, Serra AS, Tenhunen JD (1992) Environmental-effects on $\mathrm{CO}_{2}$ efflux from riparian tundra in the northern foothills of the Brooks Range, Alaska, USA. Oecologia 92: 568-577. 
Piao SL, Ciais P, Friedlingstein P, Peylin P, Reichstein M, Luyssaert S, Margolis H, Fang JY, Barr A, Chen AP, Grelle A, Hollinger DY, Laurila T, Lindroth A, Richardson AD, Vesala $\mathrm{T}$ (2008) Net carbon dioxide losses of northern ecosystems in response to autumn warming. Nature 451: 49-52.

Pleshikov FI (ed) (2002) Forest ecosystems on the Yenisei meridian. Novosibirsk, Nauka: 358.

R Core Team (2020) R: A language and environment for statistical computing. R foundation for statistical computing, Vienna, Austria. https://www.R-project.org/

Raich JW, Potter CS (1995) Global patterns of carbon dioxide emissions from soils. Global Biogeochemical Cycles 9(1): 23-36. https://doi.org/10.1029/94GB02723

Reichstein M, Tenhunen J, Roupsard O, Ourcival J-M, Rambal S, Dore S, Valentini R (2002) Ecosystem respiration in two Mediterranean evergreen Holm Oak forests: drought effects and decomposition dynamics. Functional Ecology 16: 27-39. https://doi.org/10.1046/j.0269-8463.2001.00597.x

Rencher AC, Pun FC (1980) Inflation of $\mathrm{R}^{2}$ in best subset regression. Technometrics 22: 49-53.

Scott-Denton LE, Rosenstiel TN, Monson RK (2006) Differential controls by climate and substrate over the heterotrophic and rhizospheric components of soil respiration. Global Change Biology 12: 205-216. https://doi.org/10.1111/j.1365-2486.2005.01064.x

Subke JA, Inglima I, Cotrufo MF (2006) Trends and methodological impacts in soil $\mathrm{CO}_{2}$ efflux partitioning: a meta-analytical review. Global Change Biol 12(6): 921-943. https://doi.org/10.1111/j.1365-2486.2006.01117.x

Tanaka K (2001) Multi-layer model of $\mathrm{CO}_{2}$ exchange in a plant community coupled with the water budget of leaf surfaces. Ecological Modelling 147: 85-104. https://doi.org/10.1016/S0304-3800(01)00413-6

Wickham H, Averick M, Bryan J, Chang W, McGowan LD’A, François R, Grolemund G, Hayes A, Henry L, Hester J, Kuhn M, Pedersen LT, Miller E, Bache SM, Müller K, Ooms J, Robinson D, Seidel DP, Spinu V, Takahashi K, Vaughan D, Wilke C, Woo K, Yutani H 
(2019) Welcome to the tidyverse. Journal of Open Source Software 4(43): 1686. https://doi.org/10.21105/joss.01686

Xu C, Qu JJ, Hao X, Zhu Z, Gutenberg L (2020) Monitoring soil carbon flux with in-situ measurements and satellite observations in a forested region. Geoderma 378: 114617. https://doi.org/10.1016/j.jag.2020.102156

Yan T, Qu T, Song H, Sun Z, Zeng H, Peng S (2019) Ectomycorrhizal fungi respiration quantification and drivers in three differently-aged larch plantations. Agricultural and Forest Meteorology 265: 245-251. https://doi.org/10.1016/j.agrformet.2018.11.024

Yue-Lin L, Otieno D, Owen K, Yun Z, Tenhunen J, Xing-Quan R, Yong-Biao L (2008) Temporal variability in soil $\mathrm{CO}_{2}$ emission in an orchard forest ecosystem. Pedosphere 18(3): 273-283. https://doi.org/10.1016/S1002-0160(08)60017-X

Zeng N, Mariotti A, Wetzel P (2005) Terrestrial mechanisms of interannual $\mathrm{CO}_{2}$ variability Global biogeochemical cycles 19(1): GB1016. https://doi.org/10.1029/2004GB002273

Zeng X, Song Y, Zeng C, Zhang W, He S (2016) Partitioning soil respiration in two typical forests in semi-arid regions, North China. Catena 147: 536-544. https://doi.org/10.1016/j.catena.2016.08.009 


\section{Supplementary Information}

Table 5 Models coefficients for the lichen pine forest site for each season of measurements.

\begin{tabular}{|c|c|c|c|c|c|c|c|}
\hline Model & Year & $\alpha(\mathrm{SE})$ & $\beta$ (SE) & $E_{0}$ & $\mathbf{N}$ & Adj. $\mathbf{R}^{2}$ & AIC \\
\hline \multirow[t]{6}{*}{$\mathrm{T}$ model } & All years & $\begin{array}{l}0.076^{* * *} \\
(0.008)\end{array}$ & - & 0.944 & 148 & 0.371 & 153.114 \\
\hline & 2012 & $\begin{array}{l}0.052 * * * \\
(0.012)\end{array}$ & - & 1.025 & 34 & 0.363 & 34.964 \\
\hline & 2013 & $\begin{array}{l}0.068 * * * \\
(0.014)\end{array}$ & - & 0.968 & 51 & 0.309 & 41.951 \\
\hline & 2015 & $\begin{array}{l}0.068 * * * \\
(0.014)\end{array}$ & - & 0.856 & 29 & 0.690 & 7.110 \\
\hline & 2016 & $\begin{array}{l}0.084 * * \\
(0.038)\end{array}$ & - & 0.789 & 23 & 0.152 & 20.988 \\
\hline & 2017 & $\begin{array}{l}0.080 * * * \\
(0.015)\end{array}$ & - & 0.996 & 11 & 0.736 & -3.599 \\
\hline \multirow[t]{6}{*}{$\begin{array}{l}\text { T-SWC } \\
\text { model }\end{array}$} & All years & $\begin{array}{l}0.108 * * * \\
(0.008)\end{array}$ & $\begin{array}{l}0.365 * * * \\
(0.045)\end{array}$ & 0.231 & 148 & 0.566 & 99.391 \\
\hline & 2012 & $\begin{array}{l}0.098 * * * \\
(0.013)\end{array}$ & $\begin{array}{l}0.414 * * * \\
(0.087)\end{array}$ & 0.183 & 34 & 0.618 & 18.447 \\
\hline & 2013 & $\begin{array}{l}0.109 * * * \\
(0.015)\end{array}$ & $\begin{array}{l}0.341 * * * \\
(0.076)\end{array}$ & 0.255 & 51 & 0.504 & 25.941 \\
\hline & 2015 & $\begin{array}{l}0.121 * * * \\
(0.015)\end{array}$ & $\begin{array}{l}0.182 \\
(0.114)\end{array}$ & 0.843 & 29 & 0.707 & 6.399 \\
\hline & 2016 & $\begin{array}{l}0.097 * * \\
(0.035)\end{array}$ & $\begin{array}{l}0.259^{* * *} \\
(0.119)\end{array}$ & 0.451 & 23 & 0.282 & 18.049 \\
\hline & 2017 & $\begin{array}{l}0.087 * * * \\
(0.019)\end{array}$ & $\begin{array}{l}0.155 \\
(0.218)\end{array}$ & 1.12 & 11 & 0.720 & -2.270 \\
\hline \multicolumn{8}{|c|}{$\begin{array}{l}p<0.1 ; \boldsymbol{p}<0.05 ; \mathrm{p}<0.01 \\
\mathrm{SE}-\text { standard error } \\
\mathrm{N}-\text { number of observations } \\
\text { Adj. } \mathrm{R}^{2}-\text { adjusted } \mathrm{R}^{2} \\
\text { AIC - Akaike Information Criterion }\end{array}$} \\
\hline
\end{tabular}

Table 6 Models coefficients for the feathermoss pine forest site for each season of measurements.

\begin{tabular}{|c|c|c|c|c|c|c|c|}
\hline Model & Year & $\alpha(\mathrm{SE})$ & $\beta$ (SE) & $\mathbf{E}_{0}$ & $\mathbf{N}$ & Adj. $R^{2}$ & AIC \\
\hline \multirow[t]{6}{*}{ T model } & All years & $\begin{array}{l}0.096 * * * \\
(0.012)\end{array}$ & - & 1.095 & 136 & 0.325 & 59.203 \\
\hline & 2012 & $\begin{array}{l}0.034 * \\
(0.017)\end{array}$ & - & 1.960 & 29 & 0.099 & -3.339 \\
\hline & 2013 & $\begin{array}{l}0.060 * * \\
(0.023)\end{array}$ & - & 1.392 & 47 & 0.108 & 4.815 \\
\hline & 2015 & $\begin{array}{l}0.109 * * * \\
(0.027)\end{array}$ & - & 1.036 & 28 & 0.366 & 8.883 \\
\hline & 2016 & $\begin{array}{l}0.077 \\
(0.053)\end{array}$ & - & 1.432 & 21 & 0.052 & 14.320 \\
\hline & 2017 & $\begin{array}{l}0.088 * * * \\
(0.026)\end{array}$ & - & 1.797 & 11 & 0.517 & -3.690 \\
\hline \multirow[t]{4}{*}{$\begin{array}{l}\text { T-SWC } \\
\text { model }\end{array}$} & All years & $\begin{array}{l}0.111 * * * \\
(0.010)\end{array}$ & $\begin{array}{l}0.200 * * * \\
(0.027)\end{array}$ & 1.143 & 136 & 0.519 & 13.916 \\
\hline & 2012 & $\begin{array}{l}0.091 * * * \\
(0.024)\end{array}$ & $\begin{array}{l}0.181 * * * \\
(0.059)\end{array}$ & 1.798 & 29 & 0.315 & -10.349 \\
\hline & 2013 & $\begin{array}{l}0.132 * * * \\
(0.022)\end{array}$ & $\begin{array}{l}0.328 * * * \\
(0.058)\end{array}$ & 0.340 & 47 & 0.470 & -18.664 \\
\hline & 2015 & $0.126 * * *$ & $0.351 * *$ & 0.348 & 28 & 0.481 & 4.170 \\
\hline
\end{tabular}




\begin{tabular}{lllllll}
2016 & $(0.025)$ & $(0.135)$ & & & & \\
& 0.083 & 0.113 & 2.896 & 21 & 0.031 & 15.653 \\
2017 & $(0.054)$ & $(0.149)$ & & & & \\
& $0.106^{* * *}$ & 0.101 & 3.066 & 11 & 0.522 & -3.112 \\
& $(0.031)$ & $(0.096)$ & & & & \\
\hline
\end{tabular}

$p<0.1 ; \boldsymbol{p}<0.05 ; \mathrm{p}<0.01$

SE - standard error

$\mathrm{N}$ - number of observations

Adj. $\mathrm{R}^{2}$ - adjusted $\mathrm{R}^{2}$

AIC - Akaike Information Criterion

Table 7 Models coefficients for the mixed forest site for each season of measurements.

\begin{tabular}{|c|c|c|c|c|c|c|c|}
\hline Model & Year & $\alpha(\mathrm{SE})$ & $\beta$ (SE) & $\mathbf{E}_{0}$ & $\mathbf{N}$ & Adj. $R^{2}$ & AIC \\
\hline \multirow[t]{6}{*}{$\mathrm{T}$ model } & All years & $\begin{array}{l}0.062 * * * \\
(0.010)\end{array}$ & - & 2.018 & 138 & 0.230 & 162.225 \\
\hline & 2012 & $\begin{array}{l}0.041 * * \\
(0.016)\end{array}$ & - & 1.760 & 33 & 0.146 & -5.133 \\
\hline & 2013 & $\begin{array}{l}0.060 * * * \\
(0.018)\end{array}$ & - & 1.856 & 44 & 0.192 & 6.620 \\
\hline & 2015 & $\begin{array}{l}0.137 * * * \\
(0.021)\end{array}$ & - & 1.079 & 30 & 0.594 & 8.569 \\
\hline & 2016 & $\begin{array}{l}0.212 * * * \\
(0.063)\end{array}$ & - & 0.323 & 20 & 0.349 & 21.159 \\
\hline & 2017 & $\begin{array}{l}0.031 * * * \\
(0.006)\end{array}$ & - & 3.940 & 11 & 0.734 & -8.313 \\
\hline \multirow[t]{6}{*}{$\begin{array}{l}\text { T-SWC } \\
\text { model }\end{array}$} & All years & $\begin{array}{l}0.064 * * * \\
(0.009)\end{array}$ & $\begin{array}{l}0.267 * * * \\
(0.045)\end{array}$ & 1.435 & 138 & 0.382 & 132.866 \\
\hline & 2012 & $\begin{array}{l}0.069 * * * \\
(0.023)\end{array}$ & $\begin{array}{l}0.121 \\
(0.075)\end{array}$ & 2.400 & 33 & 0.189 & -5.901 \\
\hline & 2013 & $\begin{array}{l}0.104 * * * \\
(0.018)\end{array}$ & $\begin{array}{l}0.288 * * * \\
(0.067)\end{array}$ & 0.652 & 44 & 0.431 & -7.873 \\
\hline & 2015 & $\begin{array}{l}0.161 * * * \\
(0.019)\end{array}$ & $\begin{array}{l}0.333 * * * \\
(0.098)\end{array}$ & 0.336 & 30 & 0.705 & -0.060 \\
\hline & 2016 & $\begin{array}{l}0.210 * * * \\
(0.065)\end{array}$ & $\begin{array}{l}0.098 \\
(0.242)\end{array}$ & 0.706 & 20 & 0.317 & 22.967 \\
\hline & 2017 & $\begin{array}{l}0.036 * * * \\
(0.007)\end{array}$ & $\begin{array}{l}-0.141 \\
(0.121)\end{array}$ & 38.899 & 11 & 0.744 & -8.038 \\
\hline \multicolumn{8}{|c|}{$\begin{array}{l}p<0.1 ; p<0.05 ; \mathrm{p}<0.01 \\
\mathrm{SE}-\text { standard error } \\
\mathrm{N}-\text { number of observations } \\
\text { Adj. } \mathrm{R}^{2} \text { - adjusted } \mathrm{R}^{2} \\
\mathrm{AIC}-\text { Akaike Information Criterion }\end{array}$} \\
\hline
\end{tabular}

Table 8 Models coefficients for the destroyed area for each season of measurements.

\begin{tabular}{|c|c|c|c|c|c|c|c|}
\hline Model & Year & $\alpha(\mathrm{SE})$ & $\beta$ (SE) & $\mathbf{E}_{0}$ & $\mathbf{N}$ & Adj. $R^{2}$ & AIC \\
\hline \multirow[t]{4}{*}{$\mathrm{T}$ model } & All years & $\begin{array}{l}0.070 * * * \\
(0.013)\end{array}$ & - & 0.152 & 89 & 0.248 & 211.743 \\
\hline & 2012 & $\begin{array}{l}0.080 * * * \\
(0.015)\end{array}$ & - & 0.264 & 10 & 0.760 & 6.537 \\
\hline & 2013 & $\begin{array}{l}0.076 * * * \\
(0.010)\end{array}$ & - & 0.078 & 51 & 0.535 & 55.748 \\
\hline & 2015 & $\begin{array}{l}0.116^{* * * *} \\
(0.019)\end{array}$ & - & 0.115 & 28 & 0.579 & 41.984 \\
\hline \multirow[t]{2}{*}{$\begin{array}{l}\text { T-SWC } \\
\text { model }\end{array}$} & All years & $\begin{array}{l}0.079 * * * \\
(0.013)\end{array}$ & $\begin{array}{l}-0.157 * \\
(0.085)\end{array}$ & 1.407 & 89 & 0.267 & 210.315 \\
\hline & 2012 & $0.091 * *$ & 0.167 & 0.299 & 10 & 0.730 & 8.376 \\
\hline
\end{tabular}




\begin{tabular}{cllllll}
\hline \multirow{2}{*}{2013} & $(0.036)$ & $(0.497)$ & & & & \\
& $0.082^{* * *}$ & 0.225 & 0.056 & 51 & 0.543 & 55.766 \\
2015 & $(0.011)$ & $(0.163)$ & & & & \\
& $0.112^{* * *}$ & -0.983 & 426.224 & 28 & 0.571 & 43.412 \\
\hline & $(0.020)$ & $(1.369)$ & & & & \\
\hline
\end{tabular}

$p<0.1 ; \boldsymbol{p}<0.05 ; \mathrm{p}<0.01$

SE - standard error

$\mathrm{N}$ - number of observations

Adj. $\mathrm{R}^{2}$ - adjusted $\mathrm{R}^{2}$

AIC - Akaike Information Criterion 